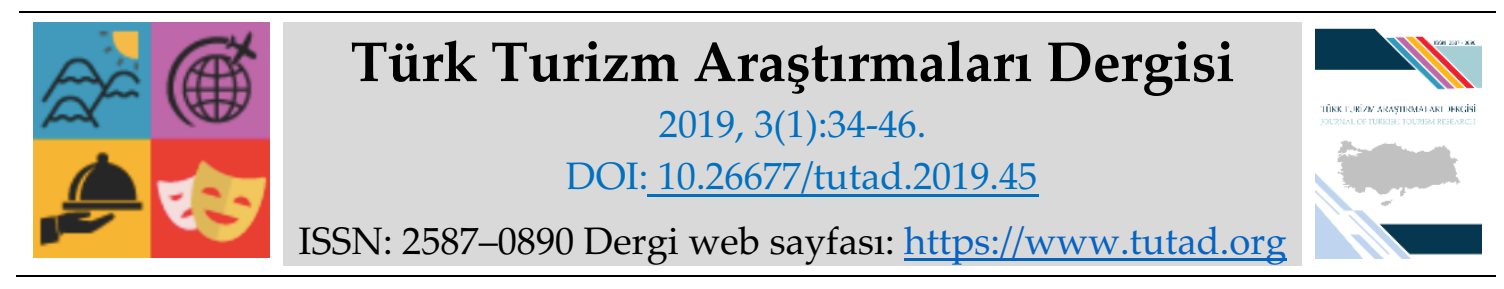

ARAŞTIRMA MAKALESI

\title{
Turizm Endüstrisinde Blogların Gücü ve Turist Rehberleri Açısından Bir Değerlendirme
}

Prof. Dr. Mithat Zeki DİNÇER, İstanbul Üniversitesi, İktisat Fakültesi, İstanbul, e-posta: mzdincer@istanbul.edu.tr

ORCID: https://orcid.org/0000-0002-4928-8303

Öğr. Gör. Dr. Tolga Fahri ÇAKMAK, Bartın Üniversitesi, Bartın Meslek Yüksekokulu, Bartın, eposta: tolgafahricakmak@gmail.com

ORCID: https://orcid.org/0000-0002-7952-1102

Arş. Gör. Merve AYDOĞAN ÇİFÇİ, İstanbul Üniversitesi, İktisat Fakültesi, İstanbul e-posta: merve.aydogan@istanbul.edu.tr

ORCID: https://orcid.org/0000-0002-7597-6951

Öz

21. yüzyılın küreselleşen dünyasında internet teknolojileri hayatın her alanında kendisini etkin bir biçimde hissettirmektedir. Öte yandan dünyanın en hızlı büyüyen endüstrilerinden biri olan turizm endüstrisi ile internet teknolojileri arasında da hızlı bir etkileşim yaşanmakta ve bu etkileşim gün geçtikçe artmaktadır. Üstelik artan bu ilişki sadece işletmelerin hizmet satışı veya reklamları odaklı olmamakta, aynı zamanda gezginlerin deneyimlerini paylaşması ve başkalarını etkilemesi noktasında da etkin bir görev üstlenmektedir. Pek çok farklı platform üzerinden gerçekleşen bu bilgi paylaşım yöntemlerinden biri de blog olarak isimlendirilen kişisel web sayfalarıdır. Kullanımı ve önemi giderek artan bloglar soyut olan hizmetin satın alınmaya karar verilmesi sürecinde önemli bir görev üstlenmektedir. Bu çalı̧mada internet teknolojileri ve özellikle blogların turizm endüstrisi üzerindeki etkileri araştırılarak geleceğe yönelik analizleri turist rehberleri üzerinden yürütülen bir çalışma ile gerçekleştirilmiştir. Çalışma kartopu örneklem yöntemi ile tespit edilen 13 adet blog yazarı turist rehberi katılımı ile gerçekleştirilmiştir. Toplanan bilgilerden hareketle, turist rehberlerinin blogları mesleki yaşamlarında nasıl kullandıkları, iş hayatlarına ve turlarına nasıl etki ettiği araştırılmış, blogların etkinliği mesleki açıdan ortaya konulmuştur.

Anahtar Kelimeler: Blog, Turizm Endüstrisi, Tur Rehberleri, İnternet Teknolojileri.

Makale Gönderme Tarihi: 22.11.2018

Makale Kabul Tarihi: 30.12 .2018

\section{Önerilen Atıf:}

Dinçer, M. Z., Çakmak, T. F. ve Aydoğan Çiftçi, M. (2019). Turizm Endüstrisinde Blogların Gücü ve Turist Rehberleri Açısından Bir Değerlendirme, Türk Turizm Araştırmaları Dergisi, 3(1):34-46.

(C) 2019 Türk Turizm Araştırmaları Dergisi. 


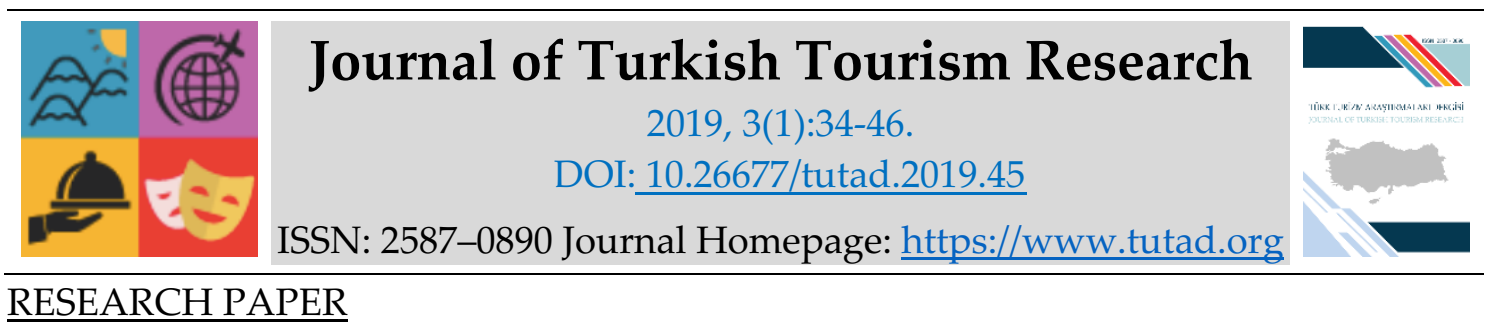

\title{
Power of Blogs in Tourism Industry and an Evaluation from Tourist Guides' Perspective
}

Prof. Dr. Mithat Zeki DİNÇER, İstanbul University, Faculty of Economics, İstanbul, e-mail: mzdincer@istanbul.edu.tr ORCID: https://orcid.org/0000-0002-4928-8303

Dr. Tolga Fahri ÇAKMAK, Bartın University, Bartın Vocational School, Bartın, e-mail: tolgafahricakmak@gmail.com

ORCID: https://orcid.org/0000-0002-7952-1102

Research Assistant. Merve AYDOĞAN ÇİFTÇİ, İstanbul University, Faculty of Economics, İstanbul e-mail: merve.aydogan@istanbul.edu.tr

ORCID: https://orcid.org/0000-0002-7597-6951

\begin{abstract}
In the 21th centuries' globalling world internet technologies have arisen effectively in almost every part of life. On the other hand, internet technologies interact with tourism industry which is most growing rapidly and this interaction is increasing day by day. Moreover, this increasing interaction is not only focused on service sales and advertisement, but also functions on travelers' experience sharing and altering other people. One of the methods which appears in different platforms is personal web pages naming blogs. Blogs which usage and significance are expanding, play a crucial role on making decision on purchasing the intangible services. In this study analyses are made intended for future according to study which is conducted by tourist guides' participation by exploring internet technologies' and particularly blogs' effects on tourism industry. The study has been conducted with 13 tourist guide who are blog writer identified by snowball sampling method. According to data collected, it's explored that how tourist guides use blogs in their professional works, how blogs affect their work life and tours and blogs effectiveness is presented in terms of professional work.
\end{abstract}

Keywords: Blog, Tourism Industry, Tourist Guides, Internet Technologies.

Received: 23.11.2018

Accepted: 30.12 .2018

\section{Suggested Citation:}

Dinçer, M. Z., Çakmak, T. F. and Aydoğan Çiftçi, M. (2019). Power of Blogs in Tourism Industry and an Evaluation from Tourist Guides' Perspective, Journal of Turkish Tourism Research, 3(1):3446.

(c) 2019 Türk Turizm Araştırmaları Dergisi. 


\section{Gíriş}

Son zamanlarda turizm de dahil olmak üzere bir çok alanda internet teknolojileri, sosyal medya ve elektronik ağızdan ağıza pazarlama gibi kavramlar sık sık incelenmeye başlamıştır. Turizm ürünlerinin özellikleri, soyut yapısı, birçok olay ve olguya karşılık kırılganlığı nedeniyle bu trendlerin turizm endüstrisine yansımalarıyla teknolojik gelişmelere karşı esnekliği incelenmesi gereken önemli bir konudur.

Turizmde ağızdan ağıza pazarlama yöntemi giderek etkisini arttırmakta, teknolojik gelişmelerle birlikte daha da gelişerek tümüyle şekil değiştirmektedir. Bu değişimin bir parçasını da bloglar teşkil etmektedir (Wang, 2015). Öte yandan blogların turizm destinasyonlarının geleceğine yön verecek boyutta çoğalmasına rağmen hak ettiği ölçüde çalışmalara konu olmadığı da ilgili literatür taramasından sonra gözlenmiştir. Oysa sosyal medya merkezli teknoloji kullanım süreçleri içerisinde bloglar; gidilen destinasyonlara yönelik tanıtımlar yapmak, hikâyeler yazmak veya deneyimler paylaşmak profesyonel bir uğraşa dönüşerek gelir getiren bir iş kolu haline gelmiştir. Ayrıca kimi noktalarda da kazanılan deneyimlerin herkese ulaştırılması açısından önemli bir aracı niteliğini teşkil etmeye başlamıştır. Blog yazarları yanı sıra devamlı bu siteleri takip edip tatil planlarını bu yaşanmış deneyimler doğrultusunda planlayan turist sayısı da gün geçtikçe artmakta, blogların okur sayısı ve takipçileri de gözle görülür biçimde artmaktadır. Bu anlamda hikaye ve görüş paylaşımı sadece seyahat edenleri değil seyahat etme potansiyeli bulunan pek çok insanı etkilediğini söylemek yanlış olmayacaktır.

Günümüzde seyahat blogları dünyada en çok takip edilen blog kategorisi içerisinde yer almaktadır. Turist rehberleri de tıpkı turistler veya gezginler gibi gezmekte fakat bu işi ayrıca hayatlarını kazanmak için yapmaktadırlar. Bu iş esnasında gezdikleri yerlerin fotoğraflarını çekmekte ve bu destinasyonlarda yaşadıkları deneyimleri bloglar aracılığı ile dünyaya duyurmaktadırlar. Bir otel ya da acentanın sahip olduğu blog kullanımından çok daha farklı olarak rehberlerin sürekli mobil konumda yeni yerlere gitmesi ve bu bölgeleri tanıtması, hem o bölgeye karşı bir merak hissi uyandırmakta hem de rehberin tanınmışlı̆̆ına da etki edebilmektedir. Bu noktada rehberlerin yazmış oldukları bloglar, kurumsal işletmelerin blog sayfalarından daha samimi ve kişisel izler taşımaktadır. Dolayısıyla çalışmanın en önemli hedeflerinden birisi rehberlerin blog yazarlıklarının mesleki kazanımlarını nasıl etkilemekte olduğunun tespit edilmesidir.

Bu çalışma mesleklerinin icra edilmesi şekli gereği turistlerle sürekli ve kesintisiz iletişim kuran ve aynı zamanda blog yazarı da olan turist rehberleri üzerine yoğunlaşmıştır. Bu amaçla blog yazarlığı yapan 13 adet turist rehberi ile yarı yapılandırılmış görüşme gerçekleştirilmiştir. Çalışmada ilk olarak internet kullanımının turizm endüstrisindeki son durumu tartışılmış, devamında blog siteleri özelinde turizmin farklılaştığı konular incelenmiş ve son olarak turist rehberlerinin görüşleri değerlendirilerek, gerçekleştirilen görüşmeler ışığında SWOT analizi uygulanmıştır.

\section{KAVRAMSAL ÇERÇEVE}

Özellikle seyahat acentaları, oteller ve destinasyon pazarlayıcıları gibi turizm işletmeleri, internet teknolojilerinin gelişmesi hususunda çağa ayak uydurma adına bir yandan ciddi bir mücadele verirken diğer yandan pek çok fırsatın kapısını da aralamaktadır (Carson, 2008). İnternet, 2000'li yılların başında tahmin bile edilemeyen şekilde iletişimi güçlendirmiş, seyahat süreçlerini kolaylaştırmış ve dağıtım kanallarını genişletmiştir (Akehurst, 2009). İlerleyen zamanlarda internet teknolojilerinin ne kadar gelişeceği veya neleri değiştirebileceği kestirilememektedir. Bu sebeple turizm ürünü ve hizmeti pazarlayan kuruluşlar, müşterilerinin gittikçe büyüyen sayıda 
sanal platformları kullandıklarını ve kullanacaklarını kabul etmelidir. Bu yüzden rakiplerinin izledikleri yolları takip etmekle beraber yeni gelişen teknolojilere de ayak uydurmak mecburiyetindedirler (Litvin vd., 2008). Aksi tutum ve davranışlar ise özellikle uluslararası piyasalarda yaşanan yoğun rekabet koşullarında geri kalma, yarışamama gibi durumları ortaya çıkartmaktadır.

Teknolojinin çok hızlı bir şekilde seyahat süreçlerini kolaylaştırdığı açıktır. Hatta teknolojik gelişmelere turistler de çok hızlı adapte olmaktadır. Öyle ki turistler için bir destinasyon hakkında bilgi sahibi olabilmek için kısa zamanda etkin bilgilere ulaşmaya yarayan blogları araştırmak bile çok zaman alır hale gelmiştir. Bu yüzden bloglardaki ilgili verilere ulaşılmayı kolaylaştırmak adına ilgi alanına göre veri kalabalığından arındırılmış, birçok bloğun kolayca tek bir anda görüntülenebilmesine olanak veren sistemler geliştirilmeye başlanmıştır (Sharda ve Ponnada, 2008). Bu da blogların seyahat kararları verirken ne kadar etkin kullanıldığını ispatlamaktadır. Bilginin kategorizasyonu ve gözetimi bu noktada bloglar üzerinde de etkin bir şekilde hissedilebilmektedir (İstanbullu Dinçer ve Çakmak: 2018) .

Yapılan çalışmalar internet teknolojilerinin gelişimi ile birlikte seyahat eden çoğu insanın destinasyonlar hakkında bilgi toplamak ve seyahat prosedürlerini gerçekleştirmek için interneti kullandığını kanıtlamaktadır. Örneğin Yoo ve Gretzel (2010) çalışmasında \%73 katılımcı tatil planında interneti kullanmıştır. Hatta bu katılımcların \% 27'si gibi önemli bir oranının seyahatlerinin tamamını; \% 31,7'sinin ise seyahatlerinin en az \% $75^{\prime}$ ini internet kullanarak gerçekleştirdiği ortaya çıkmıştır.

Google ve OTX'in 2009 yılında 6 aylık bir dönemde yaptığı araştırmaya göre internet seyahat planı için ilk sırada önemi olan kaynaktır. Aynı araştırmaya göre \% 74 iş amaçlı seyahat edenler ve \% 79 tatil amaçlı seyahat edenler seyahatlerini planlarken interneti kullanmışlardır. İş amaçlı seyahat edenlerin \%50'si, tatil amaçlı seyahat edenlerin ise \% 41'i diğer turistlerin yorumlarına ve deneyimlerine göre seyahat planı yapmaktadır. Bunun yanında arama motorları en kullanışlı internet aracıdır. Bloglar ise kullanıcı dostu arama motorları desteğiyle seyahat kararlarında önemli bir rol oynamaktadır. Yine aynı araştırmaya göre iş amaçlı seyahat edenlerin \% 25'i gittikleri yer ile ilgili yorum yazmakta, $\% 16^{\prime}$ si seyahatle ilgili bloglara katılmakta ve yine $\% 16^{\prime}$ s1 bir seyahat videosu eklemektedir (Tse ve Zhang, 2013).

Günümüzde internet teknolojisi hem turizm arzı sağlayanlar hem de talep edenler için yeni bir iletişim platformu olmuştur. Hatta internet, ağızdan ağıza pazarlamayı daha kapsamlı ve daha çok kitlelere ulaşmayı sağlayan şekline yani elektronik ağızdan ağıza pazarlamaya dönüştürmüştür. Elektronik ağızdan ağıza pazarlamanın en iyi örneği de bloglardır (Litvin vd., 2008).

Bloglar "genellikle ters kronolojik sırayla, bir web sayfası ara yüzü aracılığıyla sunulan hatıra günlüklerinin bir değişik şekli" olarak tarif edilebilir ve çoğunlukla yazar, yazının başlı̆̆ ve yazılma tarihi gibi bilgilerle başlayan bir yapı izler (Wenger, 2008). Başka bir çalışmada online günlükler olarak geçen bloglar; "yaş aralığı, milliyet, seyahat stili ve ziyaret edilen ülkeler açısından geniş bir yelpazede turist deneyimlerini incelemeyi sağlayan kolay ulaşılabilir araçlardır" şeklinde açıklanmıştır (Enoch ve Grossman, 2010).

Bloglar aslında sosyal medya genel başlığı altında bir alt başlık olsa da (Thevenot, 2007) seyahat deneyimi paylaşımı konusunda diğer sosyal medya araçlarına göre ulaştığı kitle ve paylaşılanlar açısından farklılıklar arz etmektedir. Bloglar yine internet tabanlı olan e- posta veya diğer bazı paylaşım siteleri gibi tek ya da birkaç kişinin birçok kişiye ulaşmasını değil birçok kişinin birçok kişiye ulaşmasını sağlamaktadır. Dolayısıyla bloglar turizm özelinde hem üreticinin tüketiciye, hem tüketicinin üreticiye, hem tüketicinin tüketiciye, hem de üreticinin üreticiye kolaylıkla ulaşabileceği bilgi akışı ortamı sağlar. 
Sosyal medya tabanlı bu siteleri dört ana başlık altında kategorize etmek mümkündür. Bunlar; sadece kişilerin deneyimlerinin paylaşıldığı "Kişisel Bloglar", kişilerin turizm hizmetleri ile işbirliği halinde oluşturdukları "İşbirlikçi Bloglar", turizm hizmeti veren kurumların oluşturdukları "Şirket Blogları" ve medya kurumlarının (örn; USA Today) oluşturduğu "Geleneksel Medya Blogları"dır (Thevenot, 2007).

Bloglarda verilen bilgilerin yanında kimlerin o bilgileri yazdığı da önemlidir. Yazılan mesajlar destinasyon hakkında gerçekte doğru olan ya da olmayan destinasyonun servis kalitesi, çekiciliği ve fiyat rekabeti ile ilgili abartılmış görüşler içerebilmektedir (Wenger, 2008). Bu yüzden okuyanı doğru ya da yanlış düşüncelere sevk edebilmektedir. Sonuç itibariyle bloglar kişisel, sübjektif bilgileri yansıtmaktadır.

Turizm endüstrisinde yapılan çalışmalarda blogların destinasyon pazarlamasındaki en önemli handikaplarından biri olarak dil problemi görülmektedir. Bir destinasyon hakkında yazan kişi eğer İngilizce biliyorsa çok fazla sorun görülmemekle birlikte İngilizce resmi dili olmayan bir yer için diğer dillerde yazı yazmak ulaşılmak istenen kitleyi aza indirgemektedir. Bu yüzden bloglarda sağlanması gereken bir özelliğin birden fazla dili içerebilir şekilde oluşturulmasıdır (Li ve Wang, 2011). Öte yandan günümüzde Google Translate gibi teknolojilerin giderek yapay zekâ merkezli gelişimi ve çeviri noktasında mükemmele yakın sonuçlar veriyor olması blogların dil problemini de gelecek süreçte ortadan kaldırıcı yönde ilerlemektedir.

Turizm bloglarında çoğunlukla yazılı metinler yanında fotoğraflar da paylaşılmaktadır. Bu da destinasyon hakkında yazılan bilgilerin yanı sıra okuyana görsel bir fikir verebilmektedir. Turizm pazarlayıcıları bloglarda paylaşım yapmayı desteklemeli ve olumsuz görüşler yazacakları korkusuyla blog kullanımını reddetmemelidir (Tse ve Zhang, 2013). Sonuç olarak yazılanların yanı sıra görsel kaynaklar olumsuz görüşleri destekleyebileceği gibi olumlu görüşleri de gerçeğe oranla daha etkileyici ve pozitif yapabilir.

Turizm destinasyonları özelinde bloglar hakkında yapılan çalışmaları incelemek blogların turizm endüstrisinde ne anlam ifade ettiğini anlamaya yardımcı olacaktır. Turizm endüstrisinde bloglar hakkında yapılan çalışmaların çoğu destinasyonun pazarlanması ile ilgilidir (Carson, 2008; Pühringer ve Taylor, 2008; Li ve Wang, 2011; Son, 2011; Tse ve Zhang, 2013). Bunun genel sebebi ise blog içeriklerinin araştırmalarda içerik analizi yoluyla bir destinasyon hakkında geniş bir zaman aralığı boyunca kullanışlı bilgiler içerebilmesidir (Banyai ve Glover, 2012). Bir destinasyonun güçlü ve zayıf yönlerini tespit edebilmek için de bloglar diğer veri tabanlarına göre daha kullanışlı olabilmektedir (Pan vd., 2007).

Bloglarda paylaşılan konular hakkında yapılan çalışmalar turistlerin daha çok duygu paylaşımı yaptığını göstermektedir. Chandralal vd., (2015) çalışmasında iki ünlü blog sitesinde 100 adet turistler tarafından yayınlanmış hikayeleri incelemiş ve iki ana sonuca ulaşılmıştır; blog yazarları çoğunlukla pozitif unutulmaz turist deneyimlerini yazmaktadır ve bu pozitif turist deneyimleri yedi konu üzerinde yoğunlaşmaktadır. Bu konular; (1) Yerel yaşam ve kültür, (2) Kişisel önemli deneyimler, (3) Paylaşılan deneyimler, (4) Algılanan yenilikler, (5) Algılanan tesadüfler, (6) Profesyonel yerel rehberler ve tur operatörü hizmetleri (7) Unutulmaz turist deneyimleri ile ilgili etkileyici duygulardır. Bloglar her ne kadar çoğunlukla sübjektif bilgileri içerse de bir çok kişi tarafından yazıldığında bir destinasyon hakkında genel bir izlenim edinilmesine yardımcı olmakta ve sübjektif bilgiler objektif bilgilere dönüşme yoluna girebilmektedir.

Bloglardaki turist deneyimi paylaşımı turistlerin beklentilerini, destinasyonun beklentileri karşılamadaki potansiyelini ve nihayetinde o destinasyonun imajını ortaya koyar. Bu nedenle aslında bloglar pazar bölümleme ve destinasyon markasının konumlandırılmasında oldukça önemlidir. Bir anlamda bloglar destinasyon pazarlamasını diğer geleneksel pazarlama yöntemlerinden farklı olarak eş zamanlı bilgi paylaşımı yoluyla yapmayı sağlar (Banyai, 2012: 
436). Mack vd., (2008) çalışmasında blogların güvenilirliği hakkında araştırma yapmış, eski ağızdan ağıza pazarlama yöntemlerine göre daha az güvenilir olsa da bloglar, bugün kullanılan bir çok elektronik ağızdan ağıza pazarlama yöntemine göre en güvenilir platformlardan biri olduğunu belirtmiştir. Bu sonucun online kanalların kullanımı arttıkça değişebileceği göz ardı edilmemelidir. Çünkü turizm ürünleri hali hazırda soyuttur ve deneyimler önceki bir zamanda test edilemez.

\section{ARAŞTIRMANIN AMACI VE ÖNEMI}

$\mathrm{Bu}$ araştırma, turist rehberlerinin blogları mesleki yaşamlarında kullanımlarının analizine odaklanmaktadır. Bu noktada blog yazarlığı yapan turist rehberlerine çeşitli sorular sorularak mesleki kariyer açısından önemli olduğu düşünülen sorunlar araştırılmıştır. Çalışma kapsamında sorulan sorular; turların bloglara yazılan yazılardan ne şekilde etkilendiği, bu yazıların kariyer ve ek firsatlar açısından iş yaşamına bir katkısının olup olmadığı, turistler ile olan iletişimini nasıl değiştiği gibi hususlara odaklanmaktadır. Çalışmanın önemi başta sosyal medya merkezli teknolojiler tabanlı mesleki etki araştırmalarının güncelliğine ek olarak ilgili alanda turist rehberleri üzerinde çok sınırlı sayıda araştırmanın yapılmış olmasıdır (Çakmak ve Demirkol 2017, Tekin vd., 2017). Konuyu bloglar üzerinden ele aldığımda turist rehberlerinin teknoloji kullanım düzeylerinin mesleki yaşama etkilerinin araştırıldı̆̆ı her hangi bir yayına rastlanmamıştır. Yapılan araştırmalar genel bir teknoloji kullanımı üzerine yoğunlaşmaktadır. Bu noktada blogların kulanım etkinliğinin turist rehberinin mesleki hayatına ne gibi olumlu ya da olumsuz çıktılar sunduğunun analizi önem kazanmaktadır.

\section{ARAŞTIRMANIN YÖNTEMI}

$\mathrm{Bu}$ araştırmada nitel araştırma yöntemlerinden yarı yapılandırılmış görüşme tekniği kullanılmıştır. Yöntem esnek yapısı ve araştırma esnasında ek bilgilerin de konuya dahil edilmesine izin vermesi sebebi ile tercih edilmiştir (Türnüklü, 2000). Yarı yapılandırılmış görüşme tekniğinde daha önceden hazırlanmış sorular olmakla beraber bu soruların belirli bir sırası bulunmamakta ve konunun gidişatına göre ek sorular sorulmasına fırsat vermektedir. $\mathrm{Bu}$ durum araştırmaya esneklik sağlamakla birlikte yeni bilgilerin dahil edilmesi noktasında da önemli bir artı sağlamaktadır. (Smith, 2003).

Bu çalışmada da konu ile ilgili derinlemesine bilgi sahibi olmak yanı sıra blog yazar rehber sayısının kaç tane olduğunun bilinememesi veya buna dair herhangi bir veriye ulaşılamamış olması yöntem tercihinde etkili olmuştur. Konu ile ilgili Turist Rehberleri Birliği ve en çok üyeye sahip rehberlik odası olan İstanbul Rehberler Odasına başvurulmuş fakat blog kullanan rehberler konusunda herhangi bir araştırma veya istatistik bulunmadığı öğrenilmiştir. Bu kapsamda araştırmada kartopu örneklem yolu ile toplamda 17 adet turist rehberine ulaşılmıştır. Kartopu örneklem yöntemi; ana kütlenin bilinmediği, ana kütleyi oluşturan birimlerin belirlenemediği durumlarda kullanılan bir yöntemdir. Araştırmacı araştırmak istediği kütleye ilk temasından sonra hacmi büyülterek ikinci birime oradan üçüncü birime ulaşarak amacını gerçekleştirir (Yazıcı̆̆lı ve Erdoğan, 2014).

\section{BULGULAR}

Ulaşılan 17 adet katılımcıdan 4 adet rehberin araştırma yapılan süre zarfı içerisinde, turda veya yabancı bir ülkede farklı bir dil eğitimi almakta olmalarından dolayı görüşme 
gerçekleştirilememiş olup 13 adet turist rehberi ile görüşme sağlanmıştır. Görüşmeler 20-25 dakikalık süreler içerisinde yüz yüze gerçekleştirilmiştir.

Tablo 1'de görüşme yapılan rehberlerin profesyonel rehberlik yaptıkları diller, aktif olarak rehberlik yaptıkları süreler ve blog yazarlığı yapma süreleri bulunmaktadır.

Tablo 1: Görüşme Yapılan Turist Rehberlerinin Mesleki ve Blog Kullanım Bilgileri

\begin{tabular}{|l|l|c|c|}
\hline Katılımc1 No & Rehberlik Dili & $\begin{array}{c}\text { Rehberlik } \\
\text { Süresi (yıl) }\end{array}$ & $\begin{array}{c}\text { Blog Kullanım } \\
\text { Süresi (yıl) }\end{array}$ \\
\hline Katılımc1 1 & İngilizce & 9 & 5 \\
\hline Katılımc1 2 & İngilizce - Almanca & 14 & 5 \\
\hline Katılımc1 3 & İngilizce & 6 & 3 \\
\hline Katılımc1 4 & Fransızca & 18 & 7 \\
\hline Katılımc1 5 & İtalyanca & 12 & 8 \\
\hline Katılımc1 6 & $\begin{array}{l}\text { İspanyolca- } \\
\text { Portekizce }\end{array}$ & 13 & 5 \\
\hline Katılımc1 7 & Fransızca & 9 & 6 \\
\hline Katılımc1 8 & İtalyanca & 12 & 4 \\
\hline Katılımc1 9 & İngilizce & 15 & 3 \\
\hline Katılımc1 10 & Çince & 8 & 4 \\
\hline Katılımc1 11 & Arapça & 12 & 5 \\
\hline Katılımc1 12 & Fransızca & 15 & 6 \\
\hline Katılımc1 13 & Japonca & 11 & 9 \\
\hline
\end{tabular}

Tablo 1'i incelediğimizde görüşme yapılmış olan 13 adet turist rehberinden (birden fazla dilde çalışma kartına sahip olan rehberler de dikkatte alınmak suretiyle) 4 adet İngilizce, 3adet Fransizca, 2 adet İtalyanca, 1 er adet Almanca, İspanyolca, Portekizce, Çince, Arapça ve Japonca rehber bulunmaktadır. Turist rehberlerinin profesyonel olarak turist rehberliği yapmış oldukları süreler 6 ile 18 yıl arası değişmektedir. Blog kullanım süresi ile 3 ila 8 yıl arasında değişmektedir.

Görüşmeler yarı yapılandırılmış görüşme tekniği ile tamamlanmış olup, katılımcılara sorulan temel sorular aşağıda yer almaktadır :

- Blog yazarlığının mesleki katkıları nelerdir?

- Yazdığınız yazıların turun seyrine etkisi oluyor mu?

- Blog yazarlığı yapmanın daha fazla tur yapmanıza ya da özel turlar teklif edilmesine yol açabilmek temidir?

- Blog yazarllğını diğer rehberlere de önerir misiniz?

- Farklı rehberlerin ya da bloggerların bloglarını takip eder misiniz?

- Bir seyahat yazarı- rehber olarak blog yazarken nelere dikkat edilmesi gerekir?

Araştırma kapsamında sorulan ve yukarıda yer alan sorular oda ve birlik yöneticileri ile yapılan ön görüşmeler ve ilgili literatür incelemeleri ile oluşturulmuş olup, doğrudan başka bir araştırmada kullanılan sorular kullanılmamıştır. Bunun sebebi başta rehberlik mesleğinin işletmeden ziyade bireysel olarak yapılmakta olduğu ve konu ile ilgili daha önce yapılmış herhangi bir araştırmaya rastlanılmamasıdır. Bulgular kısmında görüşme yapılan katılımcıların fikirleri genel olarak verilmiş devamında ise konu ile ilgili spesifik cevaplara değinilmiştir.

Katılımcılar "Blog yazarlığının mesleki katkıları nelerdir?" sorusuna verdiği cevaplar incelendiğinde blog kullanıcısı olmanın kendilerine olumlu bir katkı sunduklarını ifade 
etmişlerdir. Bu sayede hem güncel kalınabildiğinin hem de mevcut güncel bilgileri paylaşmanın olumlu katkılarına dikkat çekilmiş, ayrıca sadece rehberlik değil bunun yanında fotoğrafçılık, kimi gazetelerde turizm köşesinde yazarlık yapabilme gibi ek uğraşların da birer hobiye dönüştüğü ve meslekten daha fazla zevk almanın mümkün olduğu belirtilmiştir.

Katılımcı 3: Blog yazmaya başladığımdan beri teknoloji ile daha haşır neşirim, daha çok dikkatimi çekiyor bu konudaki yenilikler. Üstelik yeni teknolojilere entegre olmam konusunda da itici bir güç gibi. Örneğin akıllı telefon almamın sebebi düzenli blog yazmam, bu sayede akıllı telefonların ne kadar kullanışlı olduğunu da keşfettim, turlarda çok işime yarıyor.

Katılımcı 8: Güzel bir blog oluşturmak için güzel fotoğraflar da çekmem gerektiğini bir süre sonra diğer blogları da incelediğimde anladım ve bu konuda geçen zaman zarfında kendimi geliştirdim. Turlarda güzel noktalarda çektiğim fotoğraflar bana rotaları daha net hatırlamama hatta bu noktalarda verdiğim fotoğraf molaları ile daha olumlu turist geri dönüşleri almamı sağlamakta.

Katılımcı 9: Tura gittiğim destinasyonları bloğumda da tanıtacağım için o bölgeye ait daha etraflı araştırmalar yaptığımı da zaman içinde fark ettim. Özellikle her yeni destinasyon yeni bir blog sayfası olacağından bölgeye daha hazırlıklı gidiyor, bölgede yapılması muhtemel etkinlikleri eskiye oranla daha eksiksiz yapmaya çalışıyorum.

Katılımcı 10: Gittiğim turistik işletmelerde bloğum için fotoğraf çektiğimi gören veya bunu fark eden yerel işletme sahiplerinin kendi reklamlarının da yapılacağı algısı ile kimi zaman bana ve grubuma daha kibar davrandığını hissediyorum.

Katılımcıların "Yazdığınız yazıların turun seyrine etkisi oluyor mu?" sorusuna yanıtı ise genel olarak tur grubu ile alakalı olarak değiştiklerini bildirdiler. Kapalı ve özel ilgi turlarında bunun net bir şekilde fark edildiği ve etki ettiği söylenmekteyken, daha büyük çaplı turlarda, turun seyrini o kadar da etkilemediği bildirilmiştir.

Katılımcı 2: Kesinlikle, çalıştığım acente kurumsal firmalara tur düzenlemekte ve turist profili yönetici gruplarından oluşup genelde küçük 10-12 kişilik olmakta. Bu tarz gruplarda herhangi bir yeri değil, öncesinde araştırdıkları ve merak ettikleri bölgeleri seçmekteler. Blog'umda anlattığım ve fotoğraflarını paylaştığım yerler bu noktada karar verilmesi aşamasında etkili olduğunda muhakkak buralarda soru soruluyor, bazen tur güzergahında olmasa da grubun ortak isteği doğrultusunda rota spontane değişebiliyor.

Katılımcı 11: Özellikle V.İ.P turlarda, tur öncesi beni googledan sorgulayıp bloğuma ulaşan Arap turistlerden daha önce deneyimlerimi paylaştığım alışveriş merkezlerine gidilmesi hususunda istek geldiği oluyor. Ama bu çok da fazla gerçekleşiyor diyemem.

Katılımcı 8: Duruma göre. Örneğin sezon içinde günde 40-50 otobüs kaldıran acentaların müşterileri katıldıkları paket turu, tur esnasında öğrenmeye daha meraklı oluyorlar dolayısı ile ön hazırlığı olmayan bir grupta da blog'un pek önemi kalmıyor, küçük ve kapalı gruplarda bu durum kendisini daha da belli ediyor.

Katılımcı 5: Çok fazla etkilediğini söyleyemem ama turuma katılan birinin yazmış olduğum bloğu okuması ve bunu okuduğunu belli eden bir soru sorması insanın hoşuna gidebiliyor. Blog için harcanılan zamana değen bir geri dönüş olmuş oluyor.

Bir diğer soru olan "Blog yazarlı̆̆ı yapmanın daha fazla tur yapmanıza ya da özel turlar teklif edilmesine yol açabilmekte midir ?" sorusuna verilen yanıtlarda ise blog yazarlığına ayrılan süre ve bu işi ne kadar ilerlettiği ile alakalı olarak değişmektedir. Yazmış oldukları blogları sosyal medyada paylaşan veya ulusal gazetelerin blog sayfalarını kullanan yazarlar, özel ilgi gruplarının dikkatini çektiğini belirtmekte, blog yazarlığının diğerleri kadar üzerine düşmeyen 
rehberler ise bunu daha çok kişisel bir hobi olarak değerlendirdiklerini ve pazarlamasını yapmadıklarından turlarına yansımadıklarını söylemişlerdir.

Katılımcı 4: Elbette, ulusal bir gazetenin blog sayfasında yazılarımı yayınlıyorum, burada bir süre yazdıktan sonra kimi gazetelerde de gezi yazıları yazma şansım ortaya çıktı. Bu bölgelere tura gitmek isteyen kimi gruplardan doğrudan benimle iletişime geçenlerde olduğu gibi bu destinasyonlara tur düzenleyen acentalarda turlarına benim çıkmamı istedi.

Katılımcı 3: Açıcçası çok fazla oldu diyemem. Tanıdığım kimi blogger rehber arkadaşlar kadar bloğumun üzerine düşmüyor ya da sosyal medyada bu paylaşımları takip etmiyorum. Biraz da kendim için yazıyorum hatta.

Katılımclar "Farklı rehberlerin ya da bloggerların bloglarını takip eder misiniz?" sorusuna genel olarak inceledikleri cevabı alınmıştır. Rehberler özellikle yeni gittikleri destinasyonlarda diğer bloglardan yararlanma yoluna gitmekte, bölgeye dair tur esnasında daha işlevsel ve pratik bilgiler öğrendiklerini dile getirmişlerdir.

Katılımcı 7: Sıklıkla. Özellikle ilk defa çıkacağım rotalar öncesi bölge için hazırlanmış tanıtım siteleri yerine bloglar üzerinden araştırma yapmayı daha doğru buluyorum. Çünkü buralarda kişilerin doğrudan yaşadıkları deneyimler söz konusu. Uzun süredir takip ettiğim yazarların ise yazdıkları daha güvenli oluyor.

Katılımcı 4: Kesinlikle. Özellikle benim için yeni olan, çok bilmediğim destinasyon ve rotlarda sıklıkla baş vurmaktayım. Kimi blog yazarları ciddi manada gezme konusunda profesyoneller ve tanıtım broşürlerinde rastlayamayacağınız kıyıda köşede kalmış önemli değerlere bloglarında yer verebiliyorlar.

Katılımcı 9: Ederim. Çünkü blog yazarları bölgeye dair olumlu şeyleri yazdıkları kadar, karşılaştıkları sorunları da dile getirmekteler, örneğin bölgedeki tuvaletlerin yeterliliği, yemek yenilecek mekanlar, kültürel öğeleri yapılması ve kaçınılması gereken şeyler gibi. Bunlara broşür veya tanıtım kitaplarında rastlamak pek mümkün olmuyor açıkçası.

Katılımcılar "Blog yazarlığını diğer rehberlere önerir misiniz?" sorusuna istisnasız bir şekilde olumlu yanıt vermiş̧lerdir. Blog yazarlığı yapmanın kişide zaman içerisinde daha dikkatli olma gibi bir özellik kazandırdığı belirtilirken, blog yazmadan önce iyi bir blog okuyucusu olunmasının da gerektiğinin altı çizilmiştir.

Katılımcı 6: Kesinlikle öneririm. Meslekte yenilikler arayanlar için oldukça faydalı. Zaten turlarda deneyimlerimizi mümkün olduğunca paylaşıyoruz ama bir de bunu herkesin istediği zaman ulaşabileceği bir platform üzerinden yapmak son derece keyif verici.

Katılımcı 2: Öneririm ama çok da acele edilmemesi taraftarıyım. İyi bir blog yazarı olmak için iyi bir blog okuyucu olmak gerektiğini düşünüyorum. Ben uzun süre blog okuyuculuğu yaptıktan sonra yazmaya karar verdim. Yani benim de bir sayfam olsun mantığ 1 ile hareket etmedim. Çünkü bu yazılar ile rehber kendisine bir portföy oluşturma çabasındaysa deneyimlerini aktarma noktasında daha seçici, çektiği fotoğrafları yayınlama konusunda daha titiz olmalı.

Katılımcı 9: Blog yazarlığı özellikle yeni rotalar üzerinde çalışan rehberlerin kendilerini ve uğraşlarını tanıtmaları için bulunmaz nimet. Gidilen yöreye dair deneyim paylaşımları sizin orayı ne kadar iyi bildiğinizin adeta birer kanıtı oluyor. Bu noktada özellikle bu tarz turlar yapan kişiler için çok yararlı sanıyorum.

Katılımclar "Bir seyahat yazarı-rehber olarak blog yazarken nelere dikkat edilmesi gerekir?" sorusuna yapılan bu işin ciddiyet gerektirdiğini belirtecek şekilde cevap vermişlerdir. Gidilen 
yere dair yapılan tanıtım yazılarının artı veya eksi yönleri ile ön yargılardan arındırılarak yazılması gerektiğini bildirmişlerdir.

Katılımcı 1: Her şeyden önce doğru bilgi kullanımı çok önemli. Blog yazarlığı bir emek işi, kullanılan görseller ve verilen bilgilerin kaynağı kendisi ise bunu belirtmeli, kulaktan dolma veya doğruluğuna emin olmadığı şeyleri yazmaması gerekmekte. Özellikle bu blogları okuyup yabancı ülkelere giden kişiler aksi durumlarda zarar görebilir. Yazarlar yazdıklarının herkes tarafından okunabildiğini asla unutmamalı.

Katılımcı 2: Gidilen yere dair değerlendirmelerin dikkatli ve ön yargılardan sıyrılmış şekilde olması gerektiğini düşünüyorum. Orada yaşadığınız bir aksilik gerçekten tüm destinasyona mal edilebilir mi yoksa anlık bir şansızlık mı bunun değerlendirmesini iyi yapmalı yazar. Aynı durum olumlu şeyler içinde geçerli tabi. Yaşadığınız olumlu ve güzel şeyler bazen sadece o an ile alakalı olabiliyor.

Katılımcı 13: Neden blog yazdığınıza karar vermeniz gerekiyor. Kişisel bir hobi mi yoksa mesleki bir atılım çabası mı taşıyorsunuz? Mesleki ise seçilen kelimeler bile çok önemli. Bir yandan hitap ettiğiniz turist grubunun algısına yönelik yazmak lazım diğer yandan o bölgede tur yapma isteği uyandıracak betimelemeler, fotoğraflar kullanılmalı. Yöre insanına dair fotoğraf ve görüşmeler de oldukça ilgi çekici. İnsanların fotoğrafta gördüğü kişi ile turda karşılaşması oldukça heyecan verici bir deneyim olabiliyor.

\section{SWOT ANALIZi}

Rehberler ile yapılan yarı yapılandırılmış görüşmeler esnasında ayrıca SWOT analizinde veri olarak kullanmak amacı ile blog yazarlığının güçlü zayıf yönleri ile fırsat ve tehditler görüşme esnasında sorulmuş ve alınan yanıtlar derlenerek aşağıdaki Tablo 2 de yansıtılmıştır. Yapılmış olan bu SWOT analizinin tüm verileri çalışma kapsamında yapılmış görüşmelerden elde edilen sonuçlardan hareket ile oluşturulmuştur.

Çalışmada SWOT analizinin kullanılmasının temel sebebi görüşmeler ile elde edilen verileri tasnifi, kategorizasyonu ve ayrıştırılması sonucu blogların tam olarak mesleki katkılarının ortaya çıkartılmasıdır. Bu katkının belirlenmesinde güçlü yönler ve fırsatların belirlenmesi ilerleyen süreçte daha doğru adımların atılması noktasında büyük önem arz ederken zayıf yönler ve tehditler dikkat edilmesi gereken hususları ortaya çıkartıcı niteliktedir.

Turist rehberlerinin blog kullanımları ile ilgili yapılan SWOT analizi neticesinde güçlü yönler ve fırsatların zayıf yönler ve tehditlere oranla çok daha fazla olduğu göze çarpmaktadır. Bu bağlamda görüşme yapılan rehberler blog kullanımının kendi mesleki yaşamlarında pozitif yönlerinin belirgin şekilde daha da hissedildiğini belirtmişlerdir. Blog yazarlığının rehbere sağlamış olduğu sürekli güncel bilgi ve teknolojiye entegre görüntü bu bağlamda önem arz etmekte, rehberlerin yeni teknolojilere ulaşması hususunda öncü bir rol üstlenmektedir. Ayrıca blog yazıları ile tanınan rehberlerin özellikle kapalı tur gruplarında blogların da yazdıkları şeylerin soru olarak ya da beklenti olarak daha çok karşılarına çıktığı da belirtilmiştir. Yaratıcı fikirlerin çalınabilmesi önemli bir zayıf nokta olarak göze çarparken ücretsiz blog sitelerindeki server hatalarının tüm blog yazılarının silinmesi ile sonuçlanabildiği de belirtilmiştir. Bu sebeple blog yazmayı planlayan rehberlerin ücretli ve daha korunaklı blog alternatiflerini değerlendirmelerinin daha sağlıklı olabileceğinin altı çizilmiştir.

Rehberlerin gelirlerinin vergilendirilmesi hususundaki belirsizlik blog yazarlı̆̆ 1 ve kişisel reklam noktasında bir tehdit olarak algılanmaktadır. Verilen bilgilerin objektif olması gerekliliği veya bilgi aktarımı esnasında kullanılan dilin de yanlış anlaşılmaya mahal vermemesi gerekmektedir. 
Tablo 2: Rehberlerin Blog Yazarlıklarının Mesleki Etkilerine Üzerine Yapılmış SWOT Analizi

\begin{tabular}{|c|c|}
\hline Güçlü Yönler & Zayıf Yönler \\
\hline $\begin{array}{l}\text { - Teknolojiye hakim bir görüntü sunması } \\
\text { - Sadece rehberlik değil, sosyal ilişkiler, } \\
\text { fotoğraf çekme vs. gibi diğer yönlerde de } \\
\text { yeteneklerin turistler ile paylaşılması } \\
\text { - Tura katılan turistlerin rehber ile ilgili soru } \\
\text { işaretlerinden syyrılmaları } \\
\text { - Tura belli bir konsept veya beklenti ile } \\
\text { katılımın artması sayesinde daha amaca } \\
\text { uygun turlar ve homojen grupların oluşması } \\
\text { - Güçlü referans oluşturma etkisi } \\
\text { - Diğer rehberlik hizmeti sağlayan } \\
\text { rehberlerden güçlü olan yönleri sergileme } \\
\text { fırsatı Kişisel yaşamdaki güçlü yönleri ortaya } \\
\text { çıartarak rekabet gücü elde etme }\end{array}$ & $\begin{array}{l}\text { - Orjinal fikirlerin ve rotaların çalınabilmesi } \\
\text { veya farklı acentaların bu rotaları daha iyi } \\
\text { sunması } \\
\text { - Ücretsiz blog sitelerinin kapanabilmesi ve bu } \\
\text { site üzerine verilen emeğin boşa gitmesi } \\
\text { - Blog yazarlığının diğer sosyal medya iletişim } \\
\text { ağları ile de desteklenmesi gerekliliği }\end{array}$ \\
\hline Firsatlar & Tehditler \\
\hline $\begin{array}{l}\text { - Rehberin daha hızlı ve etkin bir şekilde ismini } \\
\text { duyurma şansı } \\
\text { - Farklı alanlardan farklı kişiler ile tanışma } \\
\text { şansı } \\
\text { - Rehberlik dışında ek işler ile uğraşabilme } \\
\text { şansı } \\
\text { - Sürecin bir getirisi olarak farklı farklı blog } \\
\text { yazarlarının takip etme eylemi ile öğrenme } \\
\text { sürecinin sürekli devam etmesi }\end{array}$ & $\begin{array}{l}\text { - Yanlış bilgilendirme } \\
\text { - Yanlış anlaşılabilme } \\
\text { - Kaçak rehberliği özendirici bir merkez haline } \\
\text { gelmesi } \\
\text { - Turist rehberliği konusunda vergilendirme } \\
\text { sıkıntıları }\end{array}$ \\
\hline
\end{tabular}

\section{SONUÇ VE ÖNERİLER}

İnternet kullanımının hayatımızın her alanına girdiği ve giderek daha da fazla yer teşkil ettiği günümüzde, bilgi akışının yoğunluğu aynı zamanda ürünlerin oluşum sürecinden, satın alımına karar verilişine kadar her süreci ilgilendirmekte ve etkilemektedir. Kişisel sayfalar olarak ortaya çıkan bloglar da bu noktada oldukça önemli bir paylaşım platformu olarak ortaya çıkmaktadır. Yapılan araştırmalarda insanların turizme katılma süreci içerisinde internetin günden güne daha önem kazandığı dikkatlerden kaçmazken blogların bu karar verme sürecinde etkinliğinin artmakta olduğu da dikkat çekmektedir. Bir anı, deneyim ya da gerçekleşmekte olan olayların birinci kişi ağzından yazıldığı seyahat blogları, ilgili destinasyonları deneyimlemiş kişilerin doğrudan fikirlerini yansıttı̆̆ kişisel sayfalardır. Dolayısı ile insanlar tatillerini burada yazan bilgiler ışığında da şekillendirebilmektedir.

Yapılmış olan bu çalışmanın en önemli amacı da gezmiş oldukları destinasyonlar ile ilgili seyahat bloğu yazıp bu bölgeleri bilfiil tanitan ve mesleğini de buna göre şekillendiren rehberlerin blogları mesleki boyutta ne kadar aktif kullandıkları, bu kullanımın mesleki ne gibi kazanımlar sunduğunun anlaşılmaya çalışılmasıdır. Bu kapsamda görüşme yapılan 13 adet blog yazarı turist rehberinden sorulan sorular eşliğinde blogları meslek hayatları içerisinde konumlandırmaları istenmiştir.

Genel itibariyle verilen cevapları değerlendirdiğimizde blogların turist rehberlerinin tanınmalarını sağlaması ve daha geniş kitlelere ulaşmaları noktasında oldukça yararlı olduğu 
görülmüştür. Turist rehberleri yazmış oldukları bloglar ile kimi zaman turistlerin kimi zamanda acentaların ilgisini çekebilmektedir. Öte yandan kimi acentalar tur yapmak istedikleri güzergah doğrultusunda ilgili destinasyonlara yönelik turlarda bu destinasyona dair geniş kapsamlı blog yazısı bulunan rehberler ile çalışmak istemişlerdir. Bloglarda verilen bilgiler bir anlamda rehberler için bir çeşit fiziksel kanıt niteliği taşımakta olduğu gözlenmiştir. Rehberin bölgede yaşadıkları, yerel halk veya yönetimler ile olan ilişkisi, çektiği fotoğraflar ve destinasyona olan hakimiyetini anlama noktasında blog yazıları kişisel portföyün oluşmasına ciddi manada katkıda bulunmaktadır.

Blog yazarlığının bir diğer yararı rehberlerin sürekli kendilerini yenileme noktasında itici bir güç niteliği oluşturmasıdır. Sürekli ve anında güncel paylaşımlar için teknolojiyi takip artarken, bloğunda yazma maksadı ile ilgili destinasyonlar üzerinde eskiye oranla daha çok çalışıldığı belirtilmiş, ayrıca fotoğraf çekme gibi hobi niteliğinde yeni alışkanlıkların kazanılmasında da etkin bir sebep sunduğu gözlenmiştir.

Bunlarla birlikte kimi rehberler orijinal fikirlerinden çıkan tur güzergahlarının blog yazıları sonrası kimi rehber veya acentalar tarafından kopya edildiğini bildirmişlerdir. Fakat bu sitelere dair en önemli sorun, rehberlerin gelirlerinin vergilendirilmesi hususunda, rehberin yazarlığının bir reklam unsuru olarak görülüp ek bir vergi külfetine girebilmesi tehlikesidir.

Elde edilen bulgular ve yorumlarından hareketle turist rehberlerinin kişisel blog sayfalarını aktif şekilde kullanmaları, güncel tutmaya özen göstermeleri, bol görsel ve açılayıcı yazılar ile bu platformu desteklemeleri önerilmektedir. Bunu yaparken fikirlerin çalınmaması noktasında stratejik açıdan önemli olan bilgi ve paylaşımlar hususunda dikkat edilmesi gerekliliği de yapılabilecek bir diğer önemli öneridir.

$\mathrm{Bu}$ çalışmanın devamı niteliğinde yine blog yazarı turist rehberlerini ilgilendirecek şekilde acentaların blogları ne şekilde takip ettikleri, takip ettikleri rehber bloggerların yazılarının turlarına rehber seçme hususunda bir etkisi olup olmadığı ölçülebilir. Ayrıca blog yazarı rehberlerin turlarına katılan turistler üzerinde bir araştırma yapılarak blog yazıları sonrası oluşan beklenti ile tur sonrası algılanan değer arasındaki fark karşılaştırılarak blogların etkinliği üzerine çalışmalar yapılabilir. Buna ek olarak turist rehberlerinin şahsi blog sayfaları kullanılan fotoğraflar, yorumlar ve gezilen yerlere göre içerik analizi uygulanarak incelenebilir.

\section{KAYNAKÇA}

Akehurst, G. (2009). User Generated Content: The Use of Blogs for Tourism Organisations and Tourism Consumers, Service Business, 3, 51-61.

Banyai, M. (2012). Travel Blogs: A Reflection of Positioning Strategies? Journal of Hospitality Marketing \& Management, 21 (4), 421-439.

Banyai, M. and Glover, T.D. (2012). Evaluating Research Methods on Travel Blogs, Journal of Travel Research, 51(3) 267-277.

Carson, D. (2008). The 'Blogosphere' As a Market Research Tool for Tourism Destinations: A Case Study of Australia's Northern Territory, Journal of Vacation Marketing, 14 (2),111-119.

Chandralal, L. Rindfleish, J. and Valenzuela, F. (2015). An Application of Travel Blog Narratives to Explore Memorable Tourism Experiences, Asia Pacific Journal of Tourism Research, 20 (6), 680693.

Çakmak, T. F. ve Demirkol, Ş. (2017). Teknolojik Gelişmelerin Turist Rehberliği Mesleğine Etkileri Üzerine Bir Swot Analizi, Bingöl Üniversitesi Sosyal Bilimler Enstitüsü Dergisi, 7(7), 221-235

Enoch, Y. and Grossman, R., (2010). Blogs of Israeli and Danish Backpackers to India. Annals of 
Tourism Research, 37 (2): 520-536.

Google and OTX. (2009). The Traveler's Road to Decision. [Online] http://www.youtube.com/watch?v=wHLNtcxSa7s [Erişim Tarihi: 10.04.2016]

İstanbullu Dinçer, F. Çakmak, T. F. ve İstanbullu Dinçer, F .(2018). Gözetim Toplumu Yönetimi ve Turizm Endüstrisi Açısından Değerlendirilmesi, Anemon Muş Alparslan Üniversitesi Sosyal Bilimler Dergisi, 6 (4): 551-558

Li, X. and Wang, Y. (2011). China in the Eyes of Western Travelers as Represented in Travel Blogs, Journal of Travel \& Tourism Marketing, 28 (7): 689-719.

Litvin, S. W. Goldsmith, R. E. and Pan, B. (2008). Electronic Word-of-Mouth in Hospitality and tourism Management. Tourism Management, 29: 458-468.

Mack, R.W. Blose, J.E. and Pan, B. (2008). Believe it or not: Credibility of Blogs in Tourism Journal of Vacation Marketing, 14 (2): 133-144.

Pan, B. Maclaurin, T. and Crotts, J.C. (2007). Travel Blogs and the Implications for Destination Marketing. Journal of Travel Research, 46(1): 35-46.

Pühringer, S. and Taylor, A. (2008). A Practitioner's Report on Blogs as a Potential Source of Destination Marketing Intelligence, Journal of Vacation Marketing, 14 (2): 177-187.

Sharda, N. and Ponnada, M. (2008). Tourism Blog Visualizer for Better Tour Planning, Journal of Vacation Marketing, 14 (2): 157-167.

Smith, M. (2003). Research Methods in Accounting, Sage Publications, İngiltere

Son, A. (2011). International Tourists' Image of Zhangiiajie, China: Content Analysis of Travel Blogs, International Journal of Culture, Tourism and Hospitality Research, 5 (3): 306 - 315.

Tekin, Ö. Bideci, M. ve Avcıkurt, C. (2017). Turist Rehberliğinde Yeni Teknolojilerin Kullanımı, (Editör) Güzel, Ö. F., Altıntaş, V., Şahin, İ.: Turist Rehberliği Araştırmaları Öngörüler ve Uygulamalar, Detay Yayınları, Ankara

Thevenot, G. (2007). Blogging as a Social Media, Tourism and Hospitality Research, 7, 287-289.

Tse, T.S.M. and Zhang, E.Y. (2013). Analysis of Blogs and Microblogs: A Case Study of Chinese Bloggers Sharing Their Hong Kong Travel Experiences, Asia Pacific Journal of Tourism Research, 18 (4): 314-329.

Türnüklü, A. (2000). Eğitimbilim Araştırmalarında Etkin Olarak Kullanılabilecek Nitel Bir Araştırma Tekniği: Görüşme, Kuram ve Uygulamada Ĕ̆itim Yönetimi, 24 (24): 543-559

Wang, P. (2005). Exploring The Influence of Electronic Word-of-Mouth on Tourists' Visit Intention a Dual Process Approach, Journal of Systems and Information Technology, 7 (4): 381-395

Wenger, A. (2008). Analysis of Travel Bloggers' Characteristics and Their Communication About Austria as a Tourism Destination. Journal of Vacation Marketing, 14 (2): 169-176.

Yazıcıoğlu, Y. ve Erdoğan, S. (2014). SPSS Uygulamalı Bilimsel Araştırma Yöntemleri, Detay Yayınları, Ankara

Yoo, K.H. Gretzel, U. (2010). Influence of Personality on Travel-Related Consumer-Generated Media Creation. Computers in Human Behavior, 27 (2): 609-621. 